
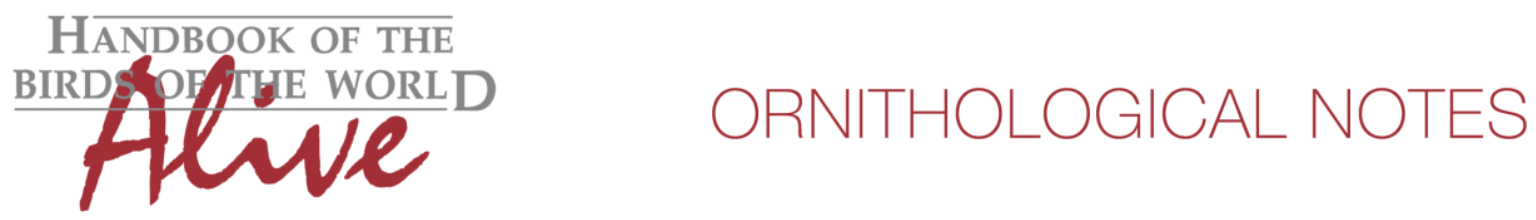

\title{
Notes on the vocalizations of Micronesian Myzomela (Myzomela rubratra)
}

Peter Boesman

In the following we briefly analyze and compare voice of the different races of Micronesian Myzomela (Myzomela rubratra). We also try to quantify the extent of any vocal differences using the criteria proposed by Tobias et al. (2010), as a support for taxonomic review.

We have made use of sound recordings available on-line from Xeno Canto (XC) and Macaulay Library (ML), and it is mainly due to the 45 recordings of Douglas Pratt that present analysis is possible.

Given that there is a wide variety of calls and the number of samples per race is small, it is far from straightforward to decide which are homologous calls. I have therefore only compared the (dawn) song.

A old recording of song without any details other than 'Guam' (saffordi) is so different that ID could be questioned (ML5592). We are then only left with samples of 3 races.

All songs are an endless series of different short melodious notes delivered at a stable moderate pace. Notes are mainly sharply downslurred, sharply overslurred and less frequently sharply upslurred. Sometimes phrases are repeated, then song switches to another phrase of several notes, sometimes no clear pattern is visible (Fig. 1).

kurodai

$$
\begin{array}{ll}
\text { min. freq. } & 1800-2200 \mathrm{~Hz} \\
\text { max. freq. } & 6000-8000 \mathrm{~Hz} \\
\text { longest note } & 0.13-0.15 \mathrm{~s}
\end{array}
$$

rubrata

$$
\begin{array}{ll}
\text { min. freq. } & 2000-2600 \mathrm{~Hz} \\
\text { max. freq. } & 5800-8350 \mathrm{~Hz} \\
\text { longest note } & 0.12-0.18 \mathrm{~s}
\end{array}
$$

dichromata

$$
\begin{array}{ll}
\text { min. freq. } & 1750-2140 \mathrm{~Hz} \\
\text { max. freq. } & 6600-8400 \mathrm{~Hz} \\
\text { longest note } & 0.12-0.18 \mathrm{~s}
\end{array}
$$

Comparison of basic sound parameters does not show any significant differences. There seems to be as much difference within races than in between races.

I have not found any distinguishing feature that would allow to separate the songs if not labeled. 


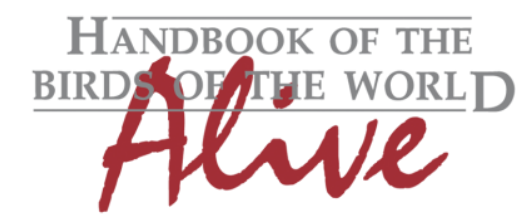

\section{ORNITHOLOGICAL NOTES}

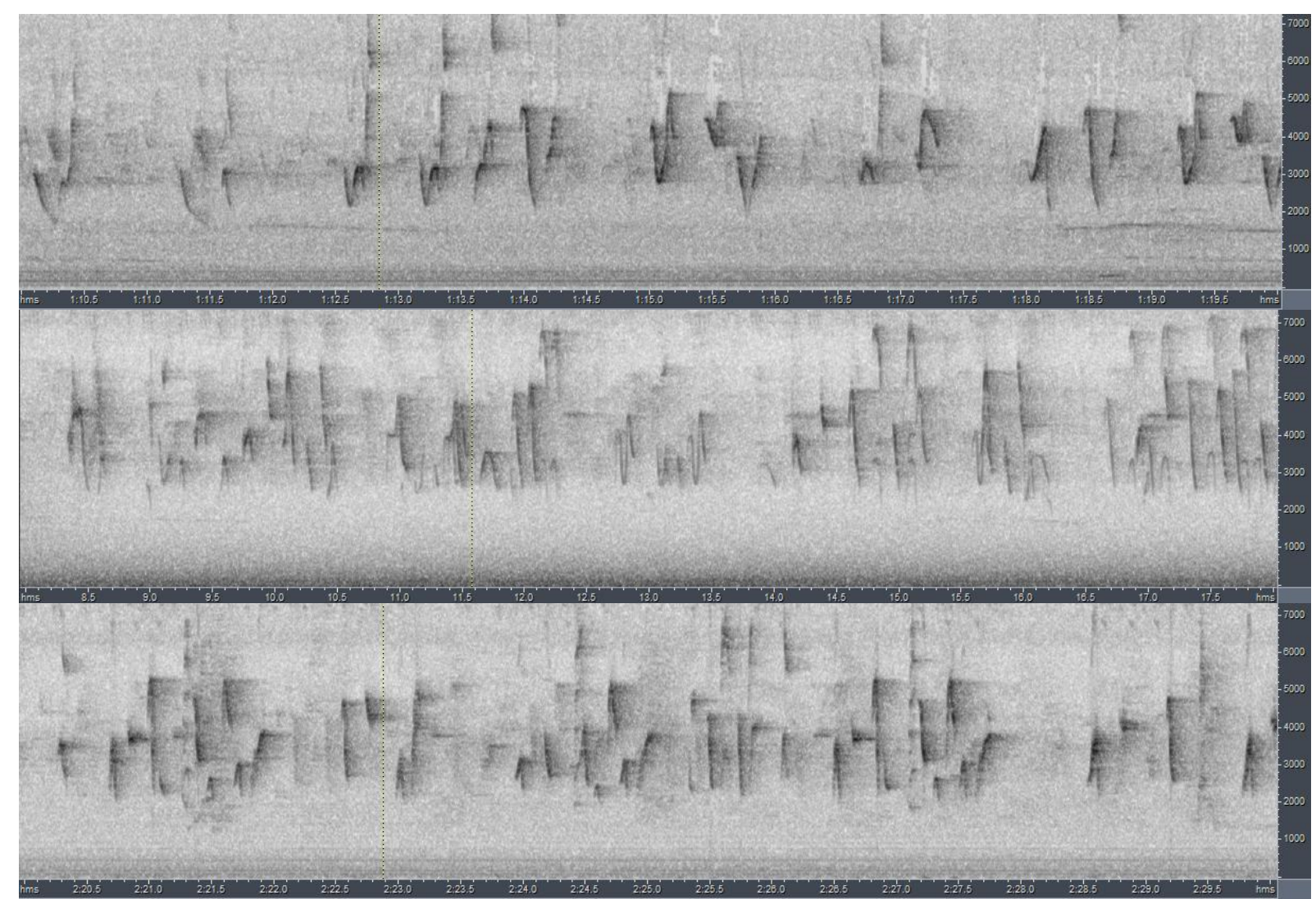

Figure 1: random examples of full song from Yap (kurodai), Kosrae (rubrata) and Pohnpei (dichromata)

This note was finalized on 29th September 2015, using sound recordings available on-line at that moment. We would like to thank in particular the sound recordists who placed their recordings for this species on XC and ML: James Bradley, Douglas Pratt and Mark Todd.

\section{References}

Tobias, J.A., Seddon, N., Spottiswoode, C.N., Pilgrim, J.D., Fishpool, L.D.C. \& Collar, N.J. (2010). Quantitative criteria for species delimitation. Ibis 152(4): 724-746.

\section{Recommended citation}

Boesman, P. (2016). Notes on the vocalizations of Micronesian Myzomela (Myzomela rubratra). HBW Alive Ornithological Note 152. In: Handbook of the Birds of the World Alive. Lynx Edicions, Barcelona. (retrieved from http://www.hbw.com/node/932082 on 17 August 2016). 